bears several white ovoid bodies attached to its wall. These are elongated and narrowing sharply distally, and they vary in size from $1.0 \mathrm{~cm} . \times 0.5 \mathrm{~cm}$. to $5.0 \mathrm{~cm} . \times 2.5 \mathrm{~cm}$. One still larger, $7.5 \mathrm{~cm} . \times$ $5.0 \mathrm{~cm}$., contains a large developing medusa. There are two fully developed young, each about $10 \mathrm{~cm}$. in diameter. These are perfect except that each has a large hole in the apex of the umbrella, presumably where they were, perhaps prematurely, separated from the stalk. They have 20 or 21 marginal sense organs and about sixty marginal lappets. Neither has any tentacles and this confirms their absence in the adult. The mouth arms are well developed and broad and filamentous. The developing gonads are already fully visible. There are many canals issuing from the stomach, all forming a very branched network of canals around the periphery as in the adult. This network runs into a continuous ring canal round the margin.

There are also four objects which I thought at first to be developing young broken away from their stalk. Two of these appear as rather featureless lumps of jelly with a honeycombed pattern. In one there is the obvious beginning of the development of a lobed umbrella margin and there is one which has de. veloped into a flat disk-like object about $10 \mathrm{~mm}$. in diameter (Fig. 2, left). This is evidently a reduced medusa, because it has ten marginal sense organs, but no mouth. The nature of these bodies must await further examination.

There is no doubt that this is an entirely new semaeostome scyphomedusa coming near the U1maridae but differing in the absence of tentacles. I am naming it Stygiomedusa fabulosa n.g., n.sp., and I hope later to be able to give a more detailed description.

The position of capture was approximately lat. $44^{\circ} \mathrm{N}$., long. $3^{\circ} 45^{\prime} \mathrm{W}$. It cannot be said from what depth the specimen actually came, but from its coloration and its habit of viviparity it must certainly normally live at great depths.

I would like to thank Capt. C. A. Hoodless and all those on board R.V. Sarsia for the care they took in preserving this specimen and bringing it back safely to the laboratory, and Mrs. E. A. Peace for taking the photographs.

\title{
CONSERVATION IN THE SCOTTISH HIGHLANDS
}

\begin{abstract}
AYMPOSIUM on "Conservation in the Scottish Highlands" was hold by the Scottish Branch of the Institute of Biology during September 29 and 30 in Glasgow, followed on October 1 by an excursion to the Black Wood and Moor of Rannoch. The following papers were read: "Problems of Conservation in the Highlands", by Prof. W. H. Pearsall (Nature Conservancy); "Geology of the Scottish Highlands and Islands", by A. C. MacGregor (Geological Survey of Great Britain, Edinburgh); "Soil Conditions in the Highland Areas", by R. Glentworth (Macaulay Institute for Soil Research, Aberdeen) ; "Soil Erosion in Scotland", by R. M. Gorrie (ex-Indian Forest Service, Edinburgh); "The Role of Bracken in Highland Ecology", by Prof. K. W. Braid (Aberdeen); "Scottish Soils in Relation to Afforestation", by W. O. Binns (Macaulay Institute for Soil Research); "Peat Afforestation", by M. V. Edwards (Forestry Commission); "The Effect of Conservation Practices on Animal Distribution", by W. J. Eggeling (Nature Conservancy) ; and "Conservation of Sheep Grazing", by R. F. Hunter (Hill Farming Research Organization). The present article is based on these papers and on the discussions which followed them, and the views expressed are not necessarily those of the reviewer.
\end{abstract}

The Scottish Highlands comprise, in a geological sense, that part of the country to the north and west of the Highland Boundary Fault. This area, in addition to the traditional crofting counties, includes more prosperous farming counties such as Aberdeenshire, Moray, Nairnshire, Banffshire and parts of Perthshire. It is in the erofting counties that the problems of depopulation, social decay and land degradation have reached serious proportions, and it is these that are causing concern.

When considering the Highlands, and conservation there, it is important first to pose the question, what are we trying to conserve ? It must be realized that this is a devastated habitat : if the human and domestic animal populations are considered, the ratio one to the other, and the density, in the poorest parts of the Highlands, are of the same order as in parts of Africa where the country is described as semidesert.

All the evidence shows that the Highlands were once much more fertile than they are to-day. Remains of large trees are found in desolate peat bogs; hillsides now bare and scree-covered show a brown forest soil below the accumulated debris of erosion. remains of human habitations are found associated with the remains of very large red deer at elevations of more than $2,000 \mathrm{ft}$., where now there is only cotton grass, heather and Nardus.

The blame for the present desolation that characterizes much of the Highlands has often been laid on a deteriorating climate, and while it seems fairly certain that the climate has got worse in the past 2,000 years-wetter and colder - this period coincides with man's first large-scale impact on Highland biological systems : the two cannot therefore be separated, but wherever deterioration has occurred, man has been present. It is therefore important to get an idea what the country was like before man interfered, if any conclusions about land-use reached are to be correct.

The Highland vegetation about 2,500 years ago consisted mainly of forest, grading into shrubby heath at 2,000-3,000 ft., which merged into arctic alpine vegetation where the hills were high enough. Tension zones would have existed between these vegetation types, and in the deteriorating climate both blanket and raised bog tended to form extensively, and these gradually killed out much forest on the higher slopes. Felling and grazing would mean retreating forests on the lower slopes. Work in another mountainous area, the English Lake District, has shown that if the nitrogen content of lake de- 
posits is taken as a measure of soil fertility at the time of deposition, and the flora of that time assessed from pollen remains, then fertility fell at the same time as the forests were cleared.

Though the natural biological system has been evolved over millennia, and is best adapted to the environment, it is not practicable to re-afforest all the land that has been eleared in the past two thousand years, and a compromise must be reached.

The failure of the 1745 rising and the break up of the clan system, with the introduction of sheep to the Highlands on a large scale for the first time, resulted in rapid devastation of the forests, aIready depleted by earlier fellings, and the slow death of large forest areas due to the prevention of natural regeneration by grazing. Sheep have thus been abundant in the Highlands for only 200 years, and though compilation of an accurate record of sheep populations presents great difficulties, it does seem that while numbers in the Highlands have declined in the past ninety years, in the Southern Uplands they have remained steady. This decline is probably due in part to too great a drain being made on the meagre natural resources of the Highland areas: the rocks are in general metamorphic formations poor in nutrients, with more fertile sedimentary deposits only occurring in quantity in Orkney, Caith. ness and the Moray Firth area. Agriculture in these areas must therefore be at a lower level of productivity than in areas more favoured geologically and climatically. Recent work by the Hill Farming Research Organization has shown that one reason for the gradual decline in the fertility of sheep runs is the feeding and manuring pattern, which causes a redistribution of nutrients from one vegetation type to another ; in addition there are the normal losses due to leaching and marketing sheep, which must be made good artificially. The high ratio of sheep to cattle has been cited as a cause of degradation, and as the presence of cattle helps to put right the damage due to differential manuring, the two animals are truly complementary; any relative increase in the numbers of cattle is therefore beneficial.

The problem of spread of bracken is important in the Highlands, and though clearance is expensive there appears to be little doubt that with modern methods much quite good land could be cleared economically.

A great increase in the land area under forest in the Highlands has already been achieved by private owners as well as by the Forestry Commission, and the Commission now has authority for "social planting' in areas where it would normally be uneconomic. The soil types available for Highland afforestation are peaty podzols with iron pan, peaty gleys, iron podzols, brown forest soils and deep peat. Peaty podzols and deep peat are two difficult types available in large amounts, and on both these the problems of establishment have been solved, now that suitable ploughing equipment has been developed and the need for additional phosphate realized; additional potash will probably be required on many peat soils. Polestage crops at least can be raised on deep peat dominated by Trichophorum, and unless windthrow proves serious, plantations should be successful in many Highland areas hitherto considered unplantable. It must be remembered, however, that blanket bog is the climatic climax in many areas.
Erosion has often resulted from deforestation, long-term overgrazing and bad draining and ploughing practices ; these causes of erosion can be eliminated, though much damage has already been done. If in the relatively equable climate of Scotland erosion never takes place on a tropical scale, sheet erosion still accounts for an enormous loss of top soil, though this is seldom admitted by farmers. The practice of repeated burning, especially on peaty soils, results in degradation of the flora and eventual erosion.

A number of interests and organizations are coneerned with the Highlands-forestry, crofting, sheep and cattle farming, the Hydroelectric Board, fishing, shooting, and not least tourism. At present, these interests tend to go their own ways. Rural develop. ment surveys of a number of Highland areas covering more than $3,000,000$ acres have recently been made by the Department of Agriculture, and in consultation with the Forestry Commission they are deciding the best division of land for each naturally demarcated area; however, there is no guarantee that owners and crofters will co-operate in these schemes.

The future of the Highlands is bound up with the future of crofting. Whether, in this age of mechanized agriculture, erofting as it is at present practised can survive is still doubtful. Unfortunately, such a haze of emotion overlies and obscures the whole subject that it is very difficult to obtain an objective view. Although where the Forestry Commission has been working on any scale the drift to the towns has been stopped, crofters are not always willing to work for the Commission, and labour may have to be brought into areas where unemployment relief was the original objective.

The integration of farming and forestry is a prerequisite of proper land use. There are, however, conflicting claims, for if lower and middle slopes of glens aro planted with trees, the ratio of inbye to hill land

usually about $6 \cdot 94$ per cent, which is already too low-will be still further lowered. A possible solution is to use red deer as grazing animals for the high tops, treating them as a natural resource. The population of red deer is admitted to be higher than the land can reasonably carry, and as it is undesirable to re-introduce the carnivores which are the natural predators, man must control their numbers. For example, the Nature Conservancy has calculated that the herd of red deer on Rhum should be reduced by a half to two-thirds, and the same is probably true for most parts of the Highlands.

A comparison with other regions may show what is needed. In Sweden, agriculture is subsidized by forestry, and English and Lowland agrieulture is effectively subsidized by industry, while in the Highlands, some of the natural resources, for example electric power and water, are exported with little or no return : the Hydroelectric Board benefits from afforestation by a reduction of the rate of silting in reservoirs, and water boards benefit from an evening-out of run-off.

Work by the Nature Conservancy, Forestry Commission Research Branch, and Hill Farming Research Organization, to mention only three bodies, is filling in many gaps in our knowledge of Highland biological systems, but the general impression the reviewer gained from this stimulating symposium was the need for more basic information, and for a more vigorous, integrated, approach to the Highland problem by all concerned.
W. O. BINNS 